\title{
Brefeldin A and Other Chemical Constituents from Endophytic Fungus Scedosporium apiospermum
}

\author{
Cordeiro, J. S.; Carvalho, J. M.; Feitosa, A. O.; Pinheiro, E. A. A.; Marinho, \\ P. S. B.; Marinho, A. M. R.*
}

Rev. Virtual Quim., 2019, 11 (1), 210-217. Data de publicação na Web: 5 de fevereiro de 2019

http://rvq.sbq.org.br

\section{Brefeldina A e Outros Constituintes Químicos do Fungo Endofítico Scedosporium apiospermum}

Resumo: Este estudo relata o isolamento de cinco compostos de Scedosporium apiospermum EJCP13 isolados como endofíticos de Bauhinia guianensis, planta típica da Amazônia. Os compostos brefeldina A (1), ergosterol (2), peróxido de ergosterol (3), cerevisterol (4) e ducitol (5) foram isolados por procedimentos cromatográficos e identificados por métodos espectroscópicos de RMN 1D e 2D e EM. O composto brefeldina A (1) apresentou boa atividade antimicrobiana e os compostos 1-5 são reportados pela primeira vez em gêneros de Scedosporium.

Palavras-chave: Brefeldina A; Scedosporium; fungo endofítico.

\section{Abstract}

This study reports the isolation of five compounds of Scedosporium apiospermum EJCP13 isolated as an endophytic of Bauhinia guianensis, a typical plant of the Amazon. The compounds brefeldin A (1), ergosterol (2), ergosterol peroxide (3), cerevisterol (4) and ducitol (5) were isolated by chromatographic procedures and identified by spectroscopic methods of $1 D$ and $2 D$ NMR and MS. The compound brefeldin A (1) showed a good antimicrobial activity and the compounds 1-5 are reported for the first time in Scedosporium genera.

Keywords: Brefeldin A; Scedosporium; endophytic fungus.

\footnotetext{
* Federal University of Pará, College of Chemistry, CEP 66075-110, Belém-PA, Brazil.

Mandrey@ufpa.br

DOI: $\underline{10.21577 / 1984-6835.20190015}$
} 


\title{
Brefeldin A and Other Chemical Constituents from Endophytic Fungus Scedosporium apiospermum
}

\author{
Jorgeffson da Silva Cordeiro, Josiwander Miranda Carvalho, André de \\ Oliveira Feitosa, Eduardo Antônio Abreu Pinheiro, Patrícia Santana \\ Barbosa Marinho, Andrey Moacir do Rosario Marinho*
}

Federal University of Pará, College of Chemistry, 66075-110, Belém-PA, Brazil.

* andrey@ufpa.br

Recebido em 18 de julho de 2018. Aceito para publicação em 11 de dezembro de 2018

1. Introduction

2. Experimental

2.1. General procedures

2.2. Plant material

2.3. Microorganism

2.4. Culture of S. apiospermum EJCP13 in rice and isolation of chemical constituents

2.5. Antimicrobial assay

2.6. Quantification of brefeldin A by UPLC/MS in S. apiospermum extracts

\section{Results and Discussion}

3.1. Antimicrobial activity of the hydro-methanolic extract of $S$. sedosporium biomass

3.2. Isolation and identification of brefeldin A

3.3. Quantitative analysis of brefeldin A content in organic extracts

\section{Conclusion}

\section{Introduction}

Among endophytic microorganisms, there are fungi and bacteria, ${ }^{1}$ but fungi are the most common isolates. ${ }^{2}$ Zhang et $a l^{3}$ state that endophytic fungi produce secondary metabolites in greater amounts than any other class of endophytic microorganisms.

As a part of a fungal community, endophytic fungi may have one or more functional roles during their life cycles. ${ }^{1}$ They can host in plants growing in different environmental regions, such as the Arctic and Antarctica, geothermal soils, deserts, oceans, forests, mangroves and coastal forests, colonizing a wide range of hosts, including algae, bryophytes, sponges, pteridophytes, gymnosperms and angiosperms..$^{4-5}$ In addition, endophytic fungi form symbiotic relationships with their hosts. These relationships may bring advantages to both the fungus and the host plant. ${ }^{6-8}$ 
The Bauhinia guianensis is typical of the Amazon region; it is used in folk medicine against infections. In previous work with $B$. guianensis compounds with antimicrobial activity were not found. ${ }^{9}$ Thus we decided to study the endophytic fungi from $B$. guianensis.

Among fungi, few papers described the genus Scedosporium as for the isolation of secondary metabolites. Huang et al. ${ }^{10}$ studied the alkaloid production of a strain of $S$. apiospermum by inducing the production of these compounds using amino acid-enriched cultures. Kuroda et al. ${ }^{11}$ reported the compound AS-1 83, which inhibits acyl-CoA, and Staerck et al. ${ }^{12}$ reported the isolation of boydone A polyketide with antiStaphylococcus aureus activity of S. boydii. The genus Scedosporium causes different infections, hence the importance of knowing more about its secondary metabolism.

In preliminary tests in our research group, we verified that the biomass extracts of $S$. apiospermum EJCP13 presented a moderate antimicrobial activity. Thus, this study describes the isolation of secondary metabolites, as well as the test of their antimicrobial activities. The compounds brefeldin A (1), ergosterol (2), ergosterol peroxide (3), cerevisterol (4) and ducitol (5) were isolated. Brefeldin A (1) showed a good antimicrobial activity and the compounds 1-5 are being reported for the first time for the genus Scedosporium.

\section{Experimental}

\subsection{General Procedures}

ESIMS data were acquired in positive and negative ion mode using a Waters Acquity TQD instrument. 1D and 2D NMR spectra were recorded on a Varian Mercury 300, using solvent signal as reference. The chemical shifts are given in delta $(\delta)$ values and the coupling constants $(J)$ in Hertz $(\mathrm{Hz})$.

\subsection{Plant material}

Bauhinia guianensis was collected in the city of Belém-PA and a voucher specimen ( $\mathrm{n}^{\circ}$ IAN 177.179) was deposited at the Herbarium of "Empresa Brasileira de Pesquisa Agropecuária" - EMBRAPA.

\subsection{Microorganism}

Scedosporium apiospermum was obtained from a collection of the Laboratório de Bioensaios e Química de Micro-organismos (LaBQuiM), Faculdade de Química Universidade Federal do Pará. This collection contains isolates from Bauhinia guianensis. One strain is deposited in the LaBQuiM with the code EJCP13.

2.4. Culture of S. apiospermum EJCP13 in rice and isolation of chemical constituents

Initially, the fungus S. apiospermum EJCP13 was cultivated on a small scale to test the antimicrobial activity of the extract. $10 \mathrm{~g}$ of rice were added into a $100 \mathrm{~mL}$ Erlenmeyer flask containing $7 \mathrm{~mL}$ of distilled water, and autoclaved for $45 \mathrm{~min}$ at $121{ }^{\circ} \mathrm{C}$. The hydromethanolic extract $(1.2 \mathrm{~g})$ was obtained at 28 days of culture. After the test of antimicrobial activity of the hydro-methanolic extract, the cultivation was carried out in an amplified scale to isolate the active compound. Twenty Erlenmeyer flasks $(1,000 \mathrm{~mL})$ containing $200 \mathrm{~g}$ rice (Tio João ${ }^{\circledR}$ ) and $100 \mathrm{~mL}$ distilled water per flask were autoclaved for $45 \mathrm{~min}$ at $121^{\circ} \mathrm{C}$. Small cubes of PDA medium containing mycelium of $S$. apiospermum EJCP13 were added in 18 Erlenmeyer flasks under sterile condition. Two flasks (with rice only) were used as control. After 28 days of growth at 25 ${ }^{\circ} \mathrm{C}$ the biomass obtained was macerated with hexane, ethyl acetate and methanol sequentially in polarity gradient. The all solvents solutions were evaporated under reduced pressure, the ethyl acetate producing a yellowish residue $(37.7 \mathrm{~g})$. Ten grams of the 
ethyl acetate extract after successive fractionations on silica gel chromatography column eluted with hexane, ethyl acetate and methanol in polarity gradient and were obtained the compounds $\mathbf{1 - 5}$.

\subsection{Antimicrobial assay}

Susceptibility of the microorganisms to the test extract and compound was determined by the microbroth dilution assay according Pinheiro et al $(2017)^{13}$. The assays were carried out with Escherichia coli (ATCC 25922), Pseudomonas aeruginosa (ATCC 27853), Staphylococcus aureus (ATCC 25923), Bacillus subtilis (ATCC 6633) and Salmonella typhimurium (ATCC14028). Bioactivity was recorded as absence of red coloration in the wells after addition of $10 \mu \mathrm{L}$ of 2,3,5triphenyltetrazolium chloride. Penicillin, vancomycin and tetracycline $(25 \mu \mathrm{g} / \mathrm{mL}$ each) were used as positive controls; the cultivation medium (MHB only) was used as negative control.

2.6. Quantification of brefeldin A by UPLC/MS in S. apiospermum extracts

For the preparation of a standard solution, $1.00 \mathrm{mg}$ of brefeldin A was solubilized in 999 $\mu \mathrm{L}$ of HPLC grade methanol, giving a stock solution at the concentration of $1,000 \mu \mathrm{g} / \mathrm{mL}$. From the stock solution, a $10 \mu \mathrm{L}$ aliquot was withdrawn, and $495 \mu \mathrm{L}$ of water and $495 \mu \mathrm{L}$ of methanol were added to a solution of 10 $\mu \mathrm{g} / \mathrm{mL}$. From this stock solution, dilutions were made to obtain solutions at concentrations of $1.0 \mu \mathrm{g} / \mathrm{mL}, 0.8 \mu \mathrm{g} / \mathrm{mL}, 0.4$ $\mu \mathrm{g} / \mathrm{mL}, 0.2 \mu \mathrm{g} / \mathrm{mL}, 0.1 \mu \mathrm{g} / \mathrm{mL}$ and $0.05 \mu \mathrm{g} / \mathrm{mL}$. Each solution was injected into the chromatographic system in triplicate. The quantification of brefeldin A was carried out from the ethyl acetate, hexane and methanolic extracts of the biomass of the endophytic fungus $S$. apiospermum. Thus, a calibration curve was plotted by varying the concentration of brefeldin $A$, and extract concentrations were fixed at $10 \mu \mathrm{g} / \mathrm{mL}$.

The calibration curve was constructed on the mass spectrometer using a $50 \mathrm{~mm} \times 2.1$ $\mathrm{mm}$ (1.7 $\mu \mathrm{m}$ pore diameter) Acquity UPLC $\mathrm{BEH}^{\oplus} \mathrm{C} 18$ analytical column, water and methanol with the addition of $0.1 \%$ TFA as the mobile phase in gradient mode from 0 to 1.4 min water/methanol at $30 \%, 1.5$ to $2.0 \mathrm{~min}$ water/methanol at $99 \%$, and finally from 2.1 to $3.5 \mathrm{~min}$ water/methanol at $30 \%$, returning to the initial condition. The flow was 0.4 $\mathrm{mL} / \mathrm{min}$, and the solvent used to dissolve the extracts was methanol.

\section{Results and Discussion}

3.1. Antimicrobial activity of the hydromethanolic extract of $S$. sedosporium biomass

For Escherichia coli, Pseudomonas aeruginosa, Staphylococcus aureus, Bacillus subtilis and Salmonella tiphymuruim, assays were carried out with the hydro-methanolic extract of the fungal biomass of the fungus $S$. sedosporium. The hydro-methanolic extract presented a moderate activity (Table 1 ). Thus, we decided to cultivate the fungus on an enlarged scale and isolate the constituent responsible for the activity.

3.2. Isolation and identification of brefeldin A

The Compound $\mathbf{1}$ was isolated from hexanic and AcOEt extracts of the biomass of the endophytic fungus $S$. apiospermum, and its structure was determined by NMR and MS. The ESIMS mass spectrum, in the positive mode, showed an ion peak in $\mathrm{m} / \mathrm{z}$ at 281 $[\mathrm{M}+\mathrm{H}]^{+}$. This information, together with RMN ${ }^{1} \mathrm{H}$ and ${ }^{13} \mathrm{C}$ data, helped to confirm the molecular formula $\mathrm{C}_{16} \mathrm{H}_{24} \mathrm{O}_{4}$ for the compound 1. The structural determination was also 
based on a comparison of RMN data from the literature. ${ }^{14}$

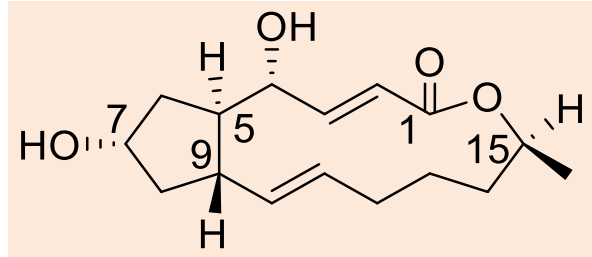

Figure 1. Structure of Compound 1

The RMN spectrum of ${ }^{1} \mathrm{H}$ showed signals for the compound 1 in $\delta_{\mathrm{H}}$ at $4.02(m, \mathrm{H}-4), \delta_{\mathrm{H}}$ 4.20 (quint., $J=5.2 \mathrm{~Hz}, \mathrm{H}-7)$ and $\delta_{\mathrm{H}} 4.80(\mathrm{~m}, \mathrm{H}-$ $15)$, characteristic of carbinolic hydrogens. It also showed signals in $\delta_{H} 5.81(d d, J=15.6$ and $2.1 \mathrm{~Hz}, \mathrm{H}-2), \delta_{\mathrm{H}} 7.44(d d, J=15.6$ and $3.0 \mathrm{~Hz}$, $\mathrm{H}-3), \delta_{\mathrm{H}} 5.26(d d, J=15.0$ and $9.6 \mathrm{~Hz}, \mathrm{H}-10)$ and $\delta_{\mathrm{H}} 5.74$ (ddd, 15.0, 10.1, $5.1 \mathrm{~Hz}, \mathrm{H}-11$ ) characteristic of olefinic hydrogens; $\mathrm{H}-3$ has a signal at $\delta_{H} 7.44$ due to the carbonyl conjugated double bond, also the signals to hidrogens $\mathrm{H}-6(2.03 \mathrm{~m}$ and $1.83 \mathrm{~m})$ and $\mathrm{H}-8$ $(2.16 \mathrm{~m}$ and $1.43 \mathrm{~m})$ were observed. In the analysis of the RMN ${ }^{13} \mathrm{C}$ spectrum, signals are observed referring to 16 carbon atoms. The carbon sign at $\delta_{\mathrm{c}} 168.4$ is characteristic of lactonic carbonyl group. The carbon signals at $\delta_{c} 155.1, \delta_{c} 138.1, \delta_{c} 131.4$ and $\delta_{c} 117.8$ were assigned to C-3, C-10 and C-11 and C-2 olefinic carbons, respectively, while the signals at $\delta c$ $76.6, \delta_{c} 73.2$ and $\delta_{c} 73.0$ were assigned to the carbinolic carbons at C-4, C-15 and C-7, respectively. Still the signals to carbons $\mathrm{C}-6$ (41.8) and C-8 (44.0) were observed to pentacyclic moiety.

The analyses of HMBC and HSQC correlations allowed determining a macrocyclic ring in $\mathbf{1}$ containing an $\alpha, \beta$ unsaturated lactone group, on the macrocycle. Through the COSY experiment, a correlation was found between $\mathrm{H}-5$ and $\mathrm{H}-9$ with a coupling constant of $9.6 \mathrm{~Hz}$, suggesting that $\mathrm{H}-5$ and $\mathrm{H}-9$ are related trans. Still following $\mathrm{HMBC}$ correlations for $\mathrm{H}-5$ and $\mathrm{H}-9$, it allowed us to propose that these hydrogens are part of a pentacyclic ring fused to the macrocycle. Thus, the compound 1 can be identified as brefeldin A. The geometry of the double bonds were inferred as being $E$ based on the characteristic values of the coupling constants. The substance brefeldin A, previously isolated from the endophytic fungus Aspergillus clavatus, has antifungal and antiviral activity and a higher cytotoxic activity than that of taxol. ${ }^{14}$

The compound 1 was tested against the bacteria $E$. coli, $P$. aeruginosa, $S$. aureus, $B$. subtilis and $S$. tiphymuruim to confirm if it was responsible for the activity verified in the hydro-methanolic extract. It presented an antimicrobial activity against the bacteria tested (Table 1). The compound $\mathbf{1}$ showed a better activity at the lowest concentration tested against $S$. tiphymuruim, which causes gastroenteritis in humans and animals.

There are few studies on the secondary metabolism of fungi of the genus Scedosporium, hence the importance of knowing the compounds produced by this important genus of fungus. In this study, besides brefeldin $A$ (1), we isolated the compounds ergosterol (2), ergosterol peroxide (3), cerevisterol (4) and ducitol (5), which are commonly isolated by fungi. Compounds 1-5 are being reported for the first time for the genus Scedosporium. All compounds were isolated by chromatographic procedures and identified by spectral methods of $1 D$ and $2 D N M R$ and MS. ${ }^{15-16}$ 
Table 1. Determination of the antibacterial activity $(\mu \mathrm{g} / \mathrm{mL})$ of the $\mathrm{MeOH}$ extract of $S$. apiospermum and Brefeldin A against Gram positive and Gram negative bacteria standard strains.

\begin{tabular}{lccccc}
\hline \multicolumn{1}{c}{ Sample } & \multicolumn{5}{c}{ Inhibitory Concentration $(\mu \mathrm{g} / \mathrm{mL})$} \\
\hline $\begin{array}{l}\text { Hydro-methanolic } \\
\text { extract }\end{array}$ & $156.25(-)$ & $156.25(-)$ & $625(-)$ & $2,500(-)$ & NP \\
Brefeldin A (1) & $62.5(-)$ & $1,250(-)$ & & & \\
Bacterium & Bs & Sa & Ec & Pa & St \\
\hline
\end{tabular}

legend: Bacillus subtilis (Bs); Staphylococcus aureus (Sa); Escherichia coli (Ec); Pseudomonas aeruginosa (Pa); Salmonella typhimurium (St); without activity (+); Bacteriostatic (-); bactericidal (=); not performed (NP).

3.3. Quantitative analysis of brefeldin A content in organic extracts

The compound 1, brefeldin A, showed a good antimicrobial activity and was the majority secondary metabolite in extracts of $S$. apiospermum. Thus, we decided to quantify this substance in crude extracts to verify the brefeldin A content in the extracts.

Experiments were initially carried out on product ions to determine the Multiple Reaction Monitoring (MRM) channels for the compound, from a fragmentation study, for a further quantification on a mass spectrometer. The MRM channels used for the quantification of brefeldin A were $281.4>$ 245.2, 281.4> 263.2 and $281.4>199.2$.

The calibration curve was plotted using the values of areas and concentrations generated from the integration of brefeldin $A$ bands into AcOEt, hexane and $\mathrm{MeOH}$ extracts. Figure 2 shows the integration band generated by brefeldin A from the AcOEt extract, where the chromatographic peak was identified with a retention time of 0.56 minutes.
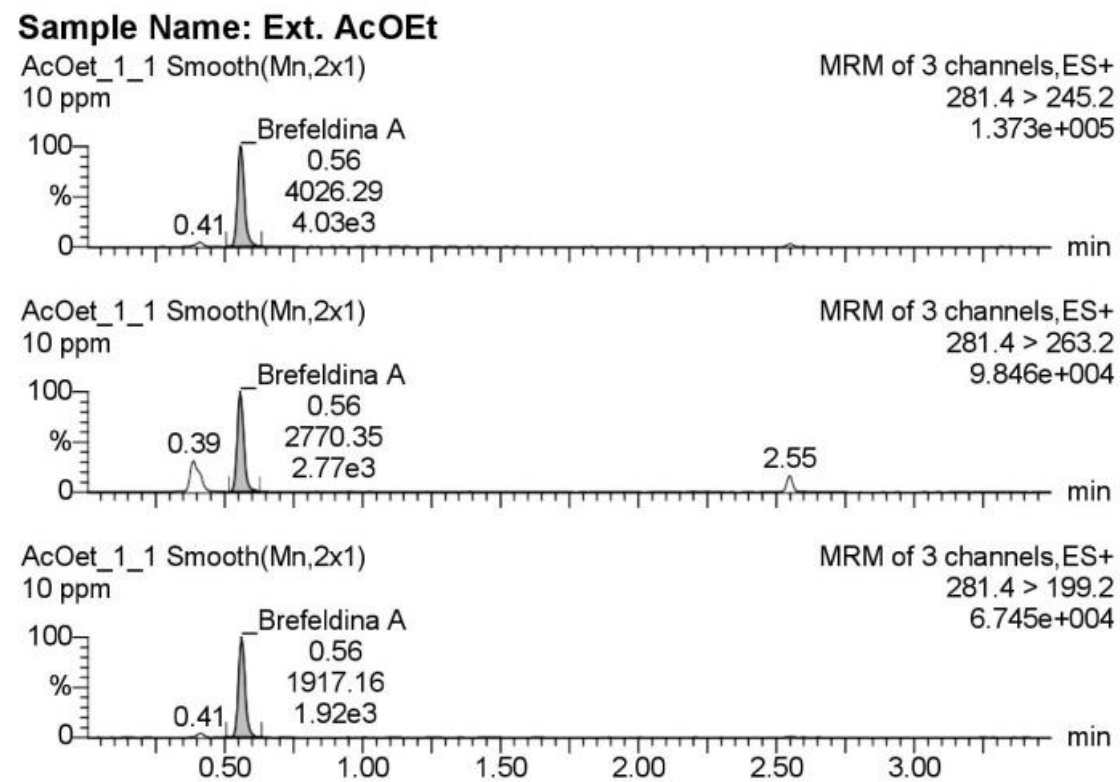

Figure 2. Integration band for the substance brefeldin A of the extract AcOEt 
From the data obtained, the calibration curve of brefeldin $A$ was plotted with the following equation: $A=9.51505 C+648.924$, where $C$ is the concentration of brefeldin $A$, and the correlation coefficient was $\mathrm{R}^{2}=0.9981$ (Figure 3 ). For the tracing of the calibration curve, the injections were performed in triplicate.

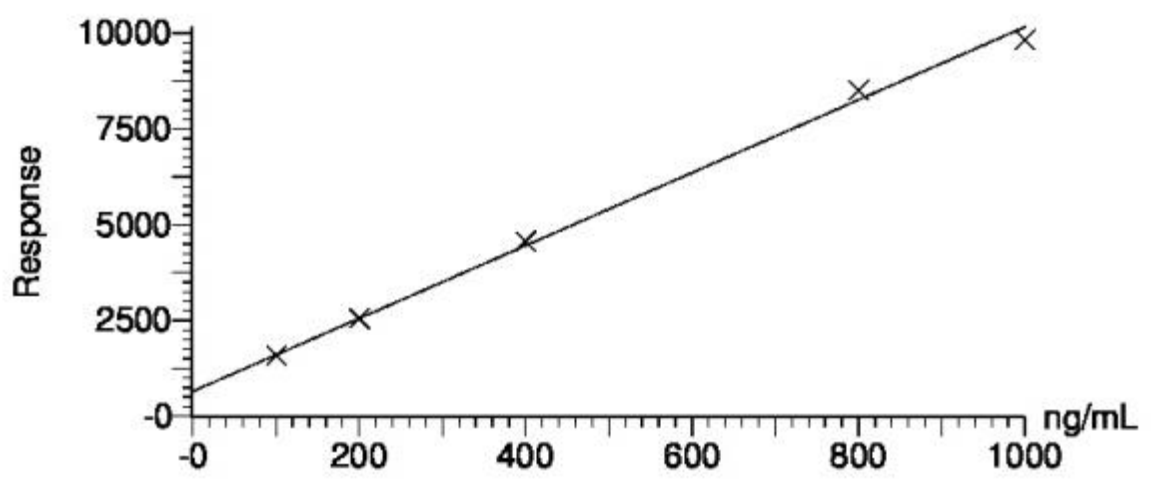

Figure 3. Brefeldin A Calibration Curve $\left(50-1,000 \mathrm{ng} \cdot \mathrm{mL}^{-1}\right)$

By interpolation of the absorption of the analyzed extracts with the calibration curve, it was possible to determine the brefeldin A content in nanogram $(\mathrm{ng})$ per milliliter $(\mathrm{mL})$ of extract. The AcOEt extract is the richest in brefeldin A, with a content of $354.9 \mathrm{ng} / \mathrm{mL}$ of the compound $\mathbf{1}$, followed by the hexane extract, with a content of $2.4 \mathrm{ng} / \mathrm{mL}$, and brefeldin A was not detected in the methanolic extract. The extract ethyl acetate showed the highest yield with $3.55 \%$ in brefeldin A.

\section{Conclusion}

The chemical study of extracts of the fungus $S$. sedosporium isolated as endophytic from $B$. guianensis showed, through quantification by UPLC/MS, that it has as major compound Brefeldin $A$, a substance that has a wide biological activity. In this work, brefeldin A (1) showed a good antimicrobial activity. Compounds 1-5 are being reported for the first time for the genus Scedosporium.

\section{Acknowledgements}

The authors thank the Fundação Amazônia Paraense de Amparo à Pesquisa (FAPESPA), Conselho Nacional de Desenvolvimento Científico e Tecnológico (CNPq) and Coordenação de Aperfeiçoamento de Pessoal de Ensino Superior (CAPES) for the financial Support.

\section{References}

${ }^{1}$ Porras-Alfaro, A.; Bayman, P. Hidden fungi, emergent properties: endophytes and microbiomes. Annual review of Phytopathology 2011, 49, 291. [CrossRef] [PubMed]

${ }^{2}$ Gunatilaka, A. A. L. Natural products from plant-associated microorganisms: distribution, structural diversity, bioactivity, and implications of their occurrence. Journal of Natural Products 2006, 69, 509. [CrossRef] [PubMed]

${ }^{3}$ Zhang, H. W.; Song, Y. C.; Tan, R. X. Biology and chemistry of endophytes. Natural Products Reports 2006, 23, 753. [PubMed] 
${ }^{4}$ Kharwar, R; Mishra, A; Gond, S; Stierle, A; Stierle, D. Anticancer compounds derived from fungal endophytes: their importance and future challenges. Natural Product Reports 2011, 28, 1208. [PubMed]

${ }^{5}$ Chowdhary, K.; Kaushik, N.; Coloma, A. G.; Raimundo, C. M. Endophytic fungi and their metabolites isolated from Indian medicinal plant. Phytochemistry Reviews 2012, 11, 467. [Link]

${ }^{6}$ Kaul, S.; Gupta, S.; Ahmed, M.; Dhar, M. K. Endophytic fungi from medicinal plants: a treasure hunt for bioactive metabolites. Phytochemistry Reviews 2012, 11, 487. [Link]

${ }^{7}$ Schulz, B.; Boyle, C. The endophytic continuum. Mycological Research 2005, 109, 661. [CrossRef]

${ }^{8}$ Saikkonen, K.; Faeth, S. H.; Helander, M.; Sullivan, T. J. Fungal endophytes: A Continuum of Interactions with Host Plants. Annual Review of Ecology and Systematics 1998, 29, 319. [CrossRef]

${ }^{9}$ Pinheiro, E. A. A.; Carvalho, J. M.; Santos, D. C. P.; Feitosa, A. O.; Marinho, P. S. B.; Guilhon, G. M. S. P.; Souza, A. D. L.; Silva, F. M.; Marinho, A. M. R. Antibacterial activity of alkaloids produced by endophytic fungus Aspergillus sp. EJC08 isolated from medical plant Bauhinia guianensis. Natural Product Research 2013, 27, 1633. [CrossRef]

${ }^{10}$ Huang, L. H; Xu, M. Y; Li, H. J; Li, J. Q.; Chen, Y. X.; Ma, W. Z.; Li, Y. P.; Xu, J.; Yang, D. P.; Lan, W. J. Amino Acid-Directed Strategy for Inducing the Marine-Derived Fungus Scedosporium apiospermum F41-1 to Maximize Alkaloid Diversity. Organic Letters 2017, 19, 4888. [CrossRef] [PubMed]

${ }^{11}$ Kuroda, K.; Yoshida, M.; Uosaki, Y.; Ando, K.; Kawamoto, I.; Oishin, E.; Onuma, H.; Yamada,
K.; Matsuda, Y. AS-183, A novel inhibitor of acyl-CoA: cholesterol acyltransferase produced by Scedosporium sp. SPC-15549. The Journal of Antibiotics 1993, 46, 1196. [CrossRef]

${ }^{12}$ Staerck, C.; Landreau, A.; Herbette, G.; Roullier, C.; Bertrand, S.; Siegler, B.; Larcher, G.; Bouchara, J. P.; Fleury, M. J. J. The secreted polyketide boydone $A$ is responsible for the anti-Staphylococcus aureus activity of Scedosporium boydii. FEMS Microbiology Letters 2017, 364, fnx223. [CrossRef] [PubMed]

${ }^{13}$ Pinheiro, E. A. A.; Pina, J. R. S.; Feitosa, A. O.; Carvalho, J. M.; Borges, F. C.; Marinho, P. S. B.; Marinho, A. M. R. Bioprospecting of antimicrobial activity of extracts of endophytic fungi from Bauhinia guianensis. Revista Argentina de Microbiología 2017, 49, 3. [CrossRef] [PubMed]

${ }^{14}$ Wang, F. W.; Jiao, R. H.; Cheng, A. B.; Tan, S. H.; Song, Y. C. Antimicrobial potentials of endophytic fungi residing in Quercus variabilis and brefeldin A obtained from Cladosporium sp. World Joural of Microbiology and Biotechnology 2007, 23, 79. [Link]

${ }^{15}$ Carvalho, J. M.; Paixão, L. K. O.; Dolabela, M. F.; Marinho, P. S. B.; Marinho, A. M. R. Phytosterols isolated from endophytic fungus Colletotrichum gloeosporioides (Melanconiaceae). Acta Amazonica 2016, 46, 69. [CrossRef]

${ }^{16}$ Souza, E. M. C.; Silva, E. L.; Marinho, A. M. R.; Marinho, P. S. B. (4S)-4,8-dihydroxy-1tetralone and other chemical constituents from Pestalotiopsis sp. EJC07, endophytic from Bauhinia guianensis. Anais da Academia Brasileira de Ciências 2016, 88, 29. [CrossRef] [PubMed] 